$$
\begin{aligned}
& (200) \\
& T 67 r \\
& \text { No. 137 }
\end{aligned}
$$

NON -PEG MA TI TI C RE SO UR CE S

OF BE R Y LL I U M IN UN I TE D ST A TE S

By L. A. Warner, W, T, Holser, V. R. Wilmarth, and E. N. Cameron

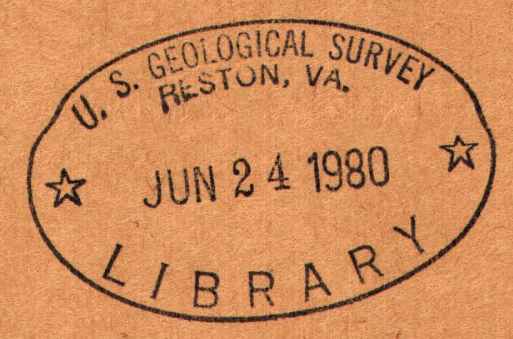

Trace Elements Investigations Report 137

UNITED STATES DEPARTMENT OF THE INTERIOR GEOLOGICAL SURVEY

ofFGLLL USE OAYY 
Geology and Mineralogy

This document consist of 10 pages.

Series A.

UNITED STATES DEPARTMENT OF THE INTERIOR

GEOLOGICAL SURVEY

NON-PEGMATITIC RESOURCES OF BERYLLIUM IN UNITED STATES*

By

L. A。 Warner, W。 T. Holser, V. R. Wilmarth, and $\mathrm{E} . \mathrm{N}$. Cameron

January 1956

Trace Elements Investigations Report 137

This preliminary report is distributed without editorial and technical review for conformity with official standards and nomenclature. It is not for public inspection or quotation.

* This report concerns work done on behalf of the Division of Raw Materials of the U. S. Atomic Energy Commission. 
Distribution (Seríes A)

Atomic Energy Commission, Washington,$\circ \circ \cdot \circ \cdot 0 \cdot 0$. Division of Raw Materials, Albuquerque $0.0,0.0 .0$.

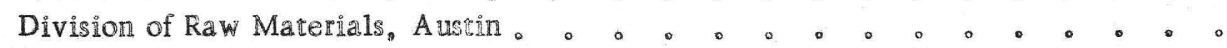
Division of Raw Materials, Butte $0 \cdot 0 \cdot 0 \cdot 0 \cdot 0 \cdot 0 \cdot 0.0$ Division of Raw Materials, Casper Division of Raw Materials, Denver Division of Raw Materials, Hot Springs Division of Raw Materials, Ishpeming Division of Raw Materials, Phoenix Division of Raw Materials, St George Division of Raw Materials, Salt Lake Cicy Division of Raw Materials, Washington Exploration Division, Grand Junction Operations Office . Grand Junction Operations Office Technical Information Service, Oak Ridge U. S。 Geological Survey: TreIs Branch.

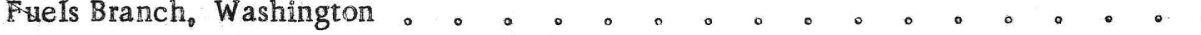
Geochemistry and Petrology Branch, Washington Geophysics Branch。Washington 。 Mineral Deposits Branch, Washington. P. C. Bateman, Menlo Park A. L. Brokaw, Grand Junction . No Mo Denson, Denver 。 $V_{0}$ L。 Freeman, College $R_{0} L_{\circ}$ Griggs, Albuquerque 。 M. R. Klepper, Spokane A. Ho Koschmann Denver 。 R. A. Laurence, Knoxville $L_{0} R_{0}$ Page, Washington Q. D. Singewald, Beltsville A. E. Weissenborn, Spokane TEPCO, Denver 。 TEPCO, RPS, Washington, (including master)
No. of copies 1

1

1

1

1

1

1

1

1

3

1

1

6

1

1

1

2

1

1

1

1

1.

1

2

1

1

1

1

2

$\frac{2}{43}$ 
CONTENTS

Abstract

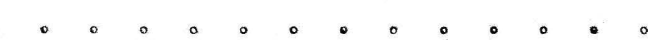

$\mathbb{I} A B L E$

Table 1. Non-pegmatite beryllium resources in Jnited States 。....$\circ$. 


\section{NON-PEGMATITIC RESOURCES OF BERYLLIUM IN UNITED STATES}

By L。 A. Wamer, W. T。 Holser, V, R。 Wilmarth, and E。 No Cameron

\section{ABSTRACT}

During the period from 1948 to 1950 , the $U_{0} S_{0}$ Geological Survey conducted a program of fielc and laboratory research to determine the mode of occurrence of beryllium in non-pegmatitic rocks and mineral deposits as part of the Beryllium Program of the Division of Raw Materials of the U. $\mathrm{S}_{0}$ Atomic Energy Commission. Approximately 23 man months were spent in the field collecting samples from 146 localities in 15 states; a total of 680 samples were collected and analyzed for beryllium. Additional samples collected by the Geological Survey, U。 S。 Bureau of Mines, various state Geological Suryeys and other institutions, and private companies were analyzed for beryllium。 In tota?, the beryllium content of 1.238 samples from about 600 localities in the United States is compiled in the final report which is being prepared for publication by the $U_{0} S_{0}$ Geological survey。 The main topics discussed are: uses and properties of beryllium; methods of analysis and mineralogy of beryllium; occurrence of beryllium in igneous, sedimentary, and metamorphic rocks, pyrometasomatic and related deposits, vein deposits, and hot spring deposits; the genesis of beryllium deposits; and a description of the deposits examined. This abstract and table 1 summarize the more pertinent economic data.

Beryllium is more abundant than arsenic, gold, silver, and molybdenum in the lithosphere, but its chemical and physical properties prohibit its concentration in minerals which are common to large commercial vein and replacement deposits. There are 29 minerals in which beryllium is an essential constituent but of these only beryl. mined from granite pegmatites, is an ore of beryllium. Beryl also occurs disseminated in granites and high-temperature veins. The other 28 minerals occur as rare constituents in syenite and granite pegmatites, granites, and pyrometasomatic deposits。 Beryllium,as a trace constituent, has been detected in 49 minerals but recovery of the beryllium requires metallurgical methods as yet unknown. 


\section{OFEICIAL USE ONLY}

5

During this investigation the beryllium content of samples from igneous, sedimentary, and metamorphic rocks, from vein deposits, and pyrometasomatic deposits was determined. The results indicate that the potential future sources of beryllium, outside of pegmatites, are granites and hightemperature veins containing fine-grained, disseminated beryl, and pyrometasomatic deposits in which helvite is the principal beryllium mineral。

The beryllium content of 42 different types of igneous rocks was determined, and with few exceptions the beryllium content was greatest in the alkalic and silicic rocks. In most of these rocks the beryllium is a trace constituent in the rock-forming minerals, but at Sheeprock Mountain, Utah, and Mount Antero, Colorado, discrete grains of beryl occur disseminated în granitre. In Sheeprock Mountains the estimated tonnages of beryl-bearing rock are several million tons; the BeO concentranges from 0.002 to 0.012 percent and the beryllium cannot be recovered economically by knowis milling techniques. The beryllium resources in the granite at Mount Antero, Colorado, are poorly known, but they are probably not large. Beryllium was detected in the alkalic rocks at Cave Peak, Texas, Wind Mountain, New Mexico, Magnet Cove, Arkansas, and Iron Hill, Colorado. The BeO content of samples of these rocks is as much as 0.03 percent, but the average is about 0.008 percent. The primcipal beryllium-bearing minerals are diopside, nephelire, and aegirite. The potential beryllium resources (table 1) in the igneous rocks are large, but the beryllium is not readily recoyerable.

The sedimentary rocks sampled contain for the most part less than 0,001 percent $B e O_{0} A$ maximum of 0.02 percent $\mathrm{BeO}$ has been found in some of the residual manganese-rich deposits in southwest Virginia. The resources are small。

The ash of a few coals from the United States was analyzed. The ash contained as much as 0.014 percent $\mathrm{BeO}$, but the distribution of the beryllium in the coal beds in not known and beryllium resources cannot be calculated without further study. It is possible that other coal beds may be found to contain even more beryllium. 
Pyrometasomatic and related deposits at 100 localities, mostly in the western United States, were sampled for beryllium. Of the 467 analyzed samples only those from 13 deposits have an average BeO content of more than 0,005 percent. Helvite-danalite is the common beryllium mineral in these deposits and is associated with idocrase, grossularite, and diopside; these minerals also contain some beryllium. The BeO content of samples from the 13 deposits rangesfrom 0.001 to 3.5 percent; those deposits in which helvite-danalite is the principal beryllium mineral are considered as potential sources of beryllium. The best known and highest grade deposit is at Iron Mountain, New Mexico, but with additional study of the deposits at Mill Creek area, Montana, and Victorio Mountains, New Mexico, significant quanticies of beryllium might be found. The estimated beryllium resources for the 13 deposits are given in table 1 .

A total of 592 samples from vein and related deposits at 123 localities in the $U_{0}$ o have been analyzed for beryllium. Of these only samples from 15 localities have an average BeO content of more than 0.005 percent. Three general types of vein deposits contain helvite and beryl: (1) quartz veins containing tin, tungsten, and molybdenum, (2) gold-quartz veins, (3) manganese-lead-zinc vein deposits. Beryllium resource data for vein deposits containing more than 0.005 percent BeO are given in table 1. The largest potential resources of beryllium in veins are in the tin-tungsten-molybdenum vein deposits.

Beryllium rarely occurs in hot spring deposits. However, samples from the Golconda manganeseiron-tungsten tufa deposits in Nevada contain as much as 0.016 percent BeO; and tufa deposits at Cove Creek。Arkansas, and Sodaville, California, contain only 0.003 and 0.007 percent BeO respectively。 The beryllium content (table 1) of these deposits is unusually high for any rock, but the mode of occurrence of the beryllium is not known; further work is necessary to evaluate the potential of these deposits as a source of beryllium. 
The resources of $\mathrm{BeO}$ in the rocks and mineral deposits listed in table 1 were calculated wherever sufficient data were available so that a reasonably accurate estimate could be made. The total estimated resources of BeO are 581 tons in igneous rocks, 426 tons in pyrometasomatic deposits and 471 tons in vein and related deposits. The largest resources of BeO are in igneous rocks, but the only potential sources are the beryl-bearing granites from which the beryl could be recovered by miling. The largest potential resources of BeO in pyrometasomatic and related deposits are in the Iron Mountain, New Mexico, helvite-bearing tactites. However, samples from the Victorio Mountains, New Mexico, Dragoon Mountains, Arizona, Mill Creek area, Montana, and the scheelite-tactite deposits in Nevada contain from 0.01 to 0.04 percent $\mathrm{BeO}$; the beryllium resources might be substantially increased in fupure geologic investigations of these deposits Beryl is the most common beryllium mineral in the vein deposirs. Helvite and phenacite are less abundant. The largest resources are in the beryl-quartz veins at the Black Pearl mine, Arizona, but substantial beryl resources may be proven with further study in other similar vein deposits of Arizona, New Mexico, and California. The unusually high BeO content of the goldbearing veins in the San Francisco district, Arizona, and Bald Mountain district, South Dakota, may prove to be potential sources of beryllium。

Future prospecting for non-pegmatitic beryllium deposits should be confined to high-temperature veins and some pyrometasomatic deposits. The association of tin, tungsten, and molybdenum with beryl has been noted in many vein deposits and seems to be a reliable guide to beryllium occurrences. In the pyrometasomatic deposits, the principal guide to beryllium minerals is the presence of fluorite. idocrase, and magnetite. Some beryllium-bearing tactites have a well developed ribbon structure。 However, all pyrometasomatic deposits showing this banding are not beryllium bearing. The importance of this structure as a guide has not been proven. A major drawback in prospecting non-pegmacitic deposits for beryllium is the lack of an efficient, simple field method for detection of beryllium. Development of such a method would facilitate the search for beryllium in non-pegmatitic deposits。 
Table 1.-NON-PEGMATITIC BERYLLIUM RESOURCES IN UNITED STATES

\begin{tabular}{|c|c|c|c|c|c|c|}
\hline \multirow[b]{2}{*}{ Location } & \multirow[b]{2}{*}{$\begin{array}{l}\text { Type of } \\
\text { Material } \\
\end{array}$} & \multirow{2}{*}{\multicolumn{2}{|c|}{$\begin{array}{l}\text { BeO (percent) } \\
\text { average }\end{array}$}} & \multicolumn{2}{|c|}{ Tonnage } & \multirow[b]{2}{*}{ Remarks } \\
\hline & & & & Rock (short tor & $2^{\mathrm{BeO}}$ & \\
\hline \multicolumn{7}{|c|}{ Igneous Rocks } \\
\hline Magnet Cove, Ark. & $\begin{array}{l}\text { Altered biotite } \\
\text { ijolite and } \\
\text { associated altered } \\
\text { sediments }\end{array}$ & Probably idocrase & $0.005-0.007$ & $5-10,000$ & 0.7 & $\begin{array}{l}\text { Beryllium probably not recoverable from the rock- } \\
\text { forming minerals. }\end{array}$ \\
\hline \multirow[t]{2}{*}{ Iron Hill, Gunnison County, Colo. } & Uncompahgrite & Diopside-hedenbergite & 0.0035 & $2-3,000,000$ & 100 & \multirow{2}{*}{$\begin{array}{l}\text { Beryllium probably not recoverable in the igneous } \\
\text { rocks or associated carbonate veins. The veins } \\
\text { contain locally as much as } 0.0097 \text { percent BeO in } \\
\text { an unknowm mineral. Resources in veins probably } \\
\text { do not exceed one ton BeO. }\end{array}$} \\
\hline & $\begin{array}{l}\text { Altered biotite } \\
\text { pyroxenite }\end{array}$ & Diopside (?) & 0.0075 & $\pm 5,000$ & 0.4 & \\
\hline $\begin{array}{l}\text { Mt. Antero area, Chaffee County, } \\
\text { Colo. }\end{array}$ & Granite & $\begin{array}{l}\text { Beryl (?) and } \\
\text { phenacite (?) }\end{array}$ & 0.018 & & & $\begin{array}{l}\text { Beryllium minerals were not identified. Analysis } \\
\text { was made of a composite sample showing no visible } \\
\text { beryl. Resources may be quite large. }\end{array}$ \\
\hline $\begin{array}{l}\text { Wind Mtn., Cornudas Mtns., New } \\
\text { Mexico. }\end{array}$ & Syenite dikes & Aegirite and nephilite & .008 & 400,000 & 30 & Beryllium is not recoverable economically. \\
\hline Cave Peak, Culberson County, Texas. & $\begin{array}{l}\text { Altered rhyolite } \\
\text { porphyry. }\end{array}$ & Unknown & 0.01 & 1,000 & 0.1 & Beryllium may not be recoverable. \\
\hline Sheeprock Mtn., Tooele County, Utah. & Granite and aplite. & Beryl & 0.004 & $(4,500,000)$ & 200 & $\begin{array}{l}\text { Beryl is finely disseminated through zones in the } \\
\text { granite and probably can be recovered only by } \\
\text { milling. Further study may disclose zones with } \\
\text { greater beryl concentrations. } \\
\text { (Revised estimates result of DMEA exploration.) }\end{array}$ \\
\hline
\end{tabular}

Pyrometasomatic ic related deposits

Carpenter district, grant County, N. Mex.

Dragoon Mtns., Cochise County, Ariz.

$$
\begin{aligned}
& \text { County, Ari } \\
& \text { Abril mine }
\end{aligned}
$$

Drumlurmon mine, Marysville, Mont.

Gallinas district, N. Mex.

Iron itn. area, Carroll County, N. H.

Iron Mtn: Sierra County, N. Mex.

Magnet Covo, Ark.
Limestone with

quartz, sulfides,

Helvite

0.01

Small

Garnet tactite

Possibly helvite

0.04

Garnet tactite

Possibly helvite

Unknown

Possibly helvite

Tactite

Hematite-magnetite- Helvite

quartz replacement

Magnetite tactite

with fluorite

Tactite

Helvite

Helvite, garnet,

Idocrase
Idocrase-phlogopite Idocrase
0.02

0.011

0.008

1.3

0.7

0.2

0.028 Helvite probably could be recovered as byproduct
but resources are small.

Resources not deternined, however 6,500 tons of lead-zinc has been produced.

Past production of 20,000 tons lead-zinc ore.

Unusually high BeO content. Distribution of the beryllium is unknown but further work seems warranted.

Resources probably small.

Helvite possibly could be recovered by milling. No production to date.

Data from R. B. Jahns.

Data from R. H. Jahns. 
Table 1.-NON-PEGMATITIC BERYLIUM RESOURCES IN UNITED STATES-Continued

Location

Type of

Material

Beryllium mineral

BeO (percent)
average

Rock Tonnage

(short tons)

\section{Pyrometasomatic and related deposits-Continued}

Mill Creek area, Anaconda, Mont.

Panther canyon area, Humbolt

Range, Nev.

Rose Creek mine, Pershing County,

Star Mine, Elko County, Nev.

Star Mine, Elko County, Nev.

Victorio district, Luna County, N. Mex.

\section{Victory Tungsten deposits, Nye}

County, Nev.

Bald Mtn. dist., Black Hidls, S. Dak.

Black Jack Clain, Sodaville dist., Mineral County, Nev.

Black Pearl mine, Yavapai County, Ariz.

Boviana district, Mohave Co., Ariz.

Boulder Creek area, Yavapai County,

California mine, Chaffee County, Colo.

Hamme mine, Vance County, N. C.

Irish Creek dist., Rockbridge County, Va.

Midnight mine, Apache dist., N. Mex. $\begin{array}{lll}\text { Idocrase-rich } & \text { Idocrase and possibly } & 0.022 \\ \text { helvite } & \text { zone } & \end{array}$

Tactite

Unknown

0.0078

Scheelite-bearing Probably helvite tactite.

Scheelite-bearing Probably helvite tactite

Marble tactite

Garnet tactite

Scheelite-bearing
silicated marble

0.02

0.007

0.006

5,000

0.35

$3,000-5,000 \max , 0.3$

$0.04 \quad 3,000-5,000 \max .2 .0$

$2-5,000$ max. one

0.02 Less than 1,000 Small

0.C14 Probably less
than 5,000 ton than one

\section{Vein and related deposits}

Cold-arsenopyrite
pyrite vein

Unknown

0.02

Manganese-tungsten Unknown

bearing vein

Beryl,

molybdenito-

wolframite quartz

Beryl-wolframitequartz veins

Beryl-wolframitequartz vein

Beryl-molybdenitequartz veins

Quartz-wolframitevein

Cassit.eritebearing quartz veins and greisen

Quartz vein with garnet epidot
Beryl

$0 . \operatorname{co75}$

$<10,000 \quad \max .0 .75$

0.05

500,000

Beryl

0.01

150,000

Beryl

Beryl

Unknown.

Fossibly beryl

0.1

100,000

0.06

12,000

0.007 Probably small

Beryl and phenacite

3,500

20
Resources not determined due to the limited number of samples collected and the complexity of the tactite zone. Possibly the resources may be quite large but further work needed.

Inadequate data to calculate resources.

Recovery of beryllium mineral probably not economical.

Estimates of $\mathrm{BeO}$ tonnage are inaccurate due to lack of geologic data. Possibly resources are large.

Resources may be increased with further study. Helvite recoverable by milling.

Potentially a large resource of beryllium.

Insufficient data to determine resources; are warrants further study.

Beryllium probably not recoverable economically.

Beryl recoverable only as a byproduct of tungsten and molybdenum milling.

Not sampled but some beryl could be recovered by milling. An important potential source of beryllium.

Beryl recoverable by milling.

Some beryl recoverable by hand cobbing, but most beryl recoverable as byproduct of $\mathrm{MoS}_{2}$ mining.

Little data on distribution of beryllium. Unlikely as a potential source of beryllium.

Beryl recoverable as byproduct of tin mining.

Past copper ore production is 5,000 tons. Some samples contain as much as $0 . \mathrm{Cl}$ percent BeO. Possible source 
Table 1.--NON-PEGMATITIC BERYLLIUM RESOURCES IN UNITED STATES--Continued

\begin{tabular}{|c|c|c|c|c|c|c|}
\hline Location & $\begin{array}{l}\text { Type of } \\
\text { Material }\end{array}$ & Beryllium mineral & $\begin{array}{l}\text { BeO (percent) } \\
\text { average }\end{array}$ & $\begin{array}{l}\text { Tonna } \\
\text { Rock } \\
\text { (short }\end{array}$ & $\begin{array}{l}\text { Beo } \\
\text { ns) }\end{array}$ & Remarks \\
\hline & \multicolumn{5}{|c|}{ Vein and related deposits-Continued } & \\
\hline $\begin{array}{l}\text { Miagara mine, Butte dist., Silver } \\
\text { Bow County, Mont. }\end{array}$ & $\begin{array}{l}\text { Lead-zinc-rhodonite } \\
\text { veins }\end{array}$ & Helvite & 0.007 & & Small & $\begin{array}{l}\text { Helvite disseminated in rhodonite veins; Recovery } \\
\text { not economical. }\end{array}$ \\
\hline $\begin{array}{l}\text { San Francisco district, Mohave } \\
\text { County, Ariz. } \\
\text { Gold Road mill } \\
\text { Gold Standard mill }\end{array}$ & $\begin{array}{l}\text { Mill tailings } \\
\text { Mill tailings }\end{array}$ & & $\begin{array}{l}0.006 \\
0.03\end{array}$ & $\begin{array}{l}400,000 \\
150,000\end{array}$ & $\begin{array}{l}20 \\
50 .\end{array}$ & $\begin{array}{l}\text { Bergllium mineral is unknown but because of the } \\
\text { high Beo content further study seems warranted. }\end{array}$ \\
\hline $\begin{array}{l}\text { Scheelite-klay mine, San Bernardino } \\
\text { County, Calif. }\end{array}$ & $\begin{array}{l}\text { Scheelite-quartz } \\
\text { vein }\end{array}$ & Beryl (?) & 0.01 & & & $\begin{array}{l}\text { Insufficient data to determine resources but } \\
\text { deposit warrants further study. }\end{array}$ \\
\hline $\begin{array}{l}\text { Tungsten King mine, Cochise County, } \\
\text { Ariz. }\end{array}$ & $\begin{array}{l}\text { Beryl-scheelite-quartz } \\
\text { reins }\end{array}$ & Beryl & 0.01 & 50,000 & 5 & $\begin{array}{l}\text { Beryl not hand-cobbable but could be an important } \\
\text { by-product of scheelite mining. }\end{array}$ \\
\hline Victorio Dist., Luna County, N. Mex. & $\begin{array}{l}\text { Beryl, wolframite- } \\
\text { quartz vein }\end{array}$ & Beryl & 0.02 & 15,000 & 3.0 & Bergl reooverable as byproduct of tungsten mining. \\
\hline $\begin{array}{l}\text { Warren and Lman, Grafton County, } \\
\text { N. H. }\end{array}$ & $\begin{array}{l}\text { Sphalerite-galena } \\
\text { vein: }\end{array}$ & Unknown & 0.006 & bly small. & & Unlikely as a potential source of beryllium. \\
\hline
\end{tabular}

